\title{
Chemical composition and mixing-state of ice residuals sampled within mixed phase clouds
}

\author{
M. Ebert ${ }^{1}$, A. Worringen ${ }^{1}$, N. Benker ${ }^{1}$, S. Mertes ${ }^{2}$, E. Weingartner ${ }^{3}$, and S. Weinbruch ${ }^{1}$ \\ ${ }^{1}$ Environmental Mineralogy, Institute of Applied Geosciences, Technical University Darmstadt, Schnittspahnstr. 9, \\ 64287 Darmstadt, Germany \\ ${ }^{2}$ Leibnitz-Institute for Tropospheric Research, 04318 Leipzig, Germany \\ ${ }^{3}$ Paul Scherrer Institut, Laboratory of Atmospheric Chemistry, 5232 Villigen, Switzerland
}

Received: 30 August 2010 - Published in Atmos. Chem. Phys. Discuss.: 12 October 2010

Revised: 10 March 2011 - Accepted: 21 March 2011 - Published: 25 March 2011

\begin{abstract}
During an intensive campaign at the high alpine research station Jungfraujoch, Switzerland, in February/March 2006 ice particle residuals within mixed-phase clouds were sampled using the Ice-counterflow virtual impactor (Ice-CVI). Size, morphology, chemical composition, mineralogy and mixing state of the ice residual and the interstitial (i.e., non-activated) aerosol particles were analyzed by scanning and transmission electron microscopy. Ice nuclei (IN) were identified from the significant enrichment of particle groups in the ice residual (IR) samples relative to the interstitial aerosol. In terms of number lead-bearing particles are enriched by a factor of approximately 25 , complex internal mixtures with silicates or metal oxides as major components by a factor of 11 , and mixtures of secondary aerosol and carbonaceous material (C-O-S particles) by a factor of 2. Other particle groups (sulfates, sea salt, Ca-rich particles, external silicates) observed in the ice-residual samples cannot be assigned unambiguously as IN. Between 9 and 24\% of all $\mathrm{IR}$ are $\mathrm{Pb}$-bearing particles. $\mathrm{Pb}$ was found as major component in around $10 \%$ of these particles $\left(\mathrm{PbO}, \mathrm{PbCl}_{2}\right)$. In the other particles, $\mathrm{Pb}$ was found as some $100 \mathrm{~nm}$ sized agglomerates consisting of 3-8 $\mathrm{nm}$ sized primary particles $(\mathrm{PbS}$, elemental $\mathrm{Pb})$. C-O-S particles are present in the IR at an abundance of 17-27\%. The soot component within these particles is strongly aged. Complex internal mixtures occur in the IR at an abundance of 9-15\%. Most IN identified at the Jungfraujoch station are internal mixtures containing anthropogenic components (either as main or minor constituent), and it is concluded that admixture of the anthropogenic component is responsible for the increased IN efficiency within
\end{abstract}

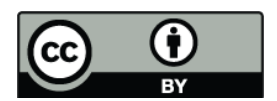

Correspondence to: M. Ebert (mebert@geo.tu-darmstadt.de) mixed phase clouds. The mixing state appears to be a key parameter for the ice nucleation behaviour that cannot be predicted from the sole knowledge of the main component of an individual particle.

\section{Introduction}

The properties and formation processes of mixed phase clouds are poorly understood (Lohmann and Feichter, 2005). Increased ice nuclei concentrations appear to decrease cloud lifetime and cloud cover leading to a warming of the atmosphere (Lohmann and Diehl, 2006). The theoretical treatment of ice nucleation is complicated by the fact that this process takes place under non-equilibrium conditions. The liquid and the vapour phases can exist metastably as supercooled water respectively supersaturated vapour. Ice formation can be initiated either by homogeneous or heterogeneous nucleation. Under ambient atmospheric conditions homogeneous nucleation takes place only in high clouds at temperatures below $-38^{\circ} \mathrm{C}$. In lower mixed phase clouds, heterogeneous nucleation dominates. In this process, ice nuclei (IN) are needed which initiate the nucleation of ice at temperatures or vapour pressures closer to the equilibrium conditions than that of homogeneous nucleation. Generally, four different modes of ice nucleation are distinguished in the literature: deposition mode, condensation mode, immersion freezing mode, and contact freezing mode (e.g., Cantrell and Heymsfield, 2005). For a special IN (e.g. kaolinite), each mode is characterized by a specific threshold temperature and supersaturation value frequently plotted as temperature/supersaturation curve (e.g., Schaller and Fukuta, 1979; Zimmermann et al., 2007, 2008). 
It was found that a number of properties can increase the ability of a special particle to act as IN including the structural match between the substrate and the ice crystal, low water solubility, hydrogen bonds at the IN surface, larger size of the IN, electric field, and the presence of active sites on the surface (e.g. Eidhammer et al., 2009).

At temperatures below $-12{ }^{\circ} \mathrm{C}$, natural mineral dust particles, mostly clay minerals as kaolinite, illite or montmorillonite are thought to dominate the atmospheric nucleation of ice (e.g., Mason, 1971; Eastwood et al., 2008). At higher temperatures, biological IN may play an important role as the highest temperatures of ice nucleation were reported for specific bacteria (e.g., Schnell and Vali, 1972; Möhler et al., 2007). Silicates emitted by volcanic eruptions were also considered as a possible source for IN (Isono et al., 1959; Hobbs et al., 1971; Durant et al., 2008) and indeed enhanced IN concentrations during a volcanic ash event were measured by Bingemer et al. (2011).

However, according to Szyrmer and Zawadzki (1997) the theory of heterogeneous ice nucleation as well as the available measuring techniques still have limitations that prevent an accurate quantitative description (on a molecular scale) of the nucleation process in mixed-phase clouds. In addition, the transfer of results from laboratory investigations to complex ambient atmospheric systems remains difficult.

Therefore, identification and detailed characterization of particles that have acted as IN in mixed phase clouds is important for a better understanding of the ice-forming processes. In the last decades, a variety of measurements were performed in order to determine the physico-chemical properties and the most important sources of IN. In these studies, small fresh ice particles are collected and it is assumed that the observed ice residual material (IR) has acted as IN (i.e., incorporation of additional particles into the ice grain can be neglected). IR sampling was performed in a variety of studies from different aircraft platforms (e.g., Cziczo et al., 2004; Prenni et al., 2007; Targino et al., 2006; Twohy and Poellot, 2005), and at high-altitude mountain top sites using diffusional growth chambers (e.g., DeMott et al., 2003; Richardson et al., 2007). In a variety of experiments as M-PACE (Prenni et al., 2009), SUCCESS (Chen et al., 1998), NASA Crystal-FACE (De Mott et al., 2003a), NASA Fire-ACE (Rogers et al., 2001), INSPECT-1 (De Mott et al., 2003b) and -2 (Richardson et al., 2009) IR sampling was realized within mixed phase clouds. Following the classification of Chen et al. (1998) three kind of IR were determined in these experiments. "Dust and metallic material" (including alumosilicates, metal oxide particles and mixtures of these particles with sulfates), "Carbonaceous particles" (including insoluble organic particles and/or soot and mixtures of these particles with sulfates) and "other" particles (including chlorine rich particles and complex mixtures of different particle types).

Such ambient IR measurements are always associated with large uncertainties as the IN concentration are about six or- ders of magnitude lower than the total particle concentrations in a mixed phase cloud. In addition, ice nucleation may be initiated by surface coatings, heterogeneous inclusions or even a single ice nucleation protein on bacterial cells that are often non-detectable with current instrumentation.

In the present contribution the Ice-CVI (Mertes et al., 2007) is used for the sampling of ice particle residuals within clouds at the high alpine Jungfraujoch research station. At the temperature range present during this experiment $(-27$ to $-12{ }^{\circ} \mathrm{C}$ ) a significant amount of all observed clouds will be mixed-phase clouds, but it cannot be excluded that some pure ice-clouds were also present. The main purpose of our study is the detailed characterization of the chemical composition and the mixing-state of the received ice residuals (IR).

\section{Experimental}

In February/March 2006 the Cloud and Aerosol Characterization Experiment (CLACE-5) was conducted at the high alpine research station Jungfraujoch (JFJ, $3580 \mathrm{~m}$ a.s.1.; $46.55^{\circ} \mathrm{N}, 7.98^{\circ} \mathrm{E}$ ) in Switzerland. This high-alpine site enables ground-based sampling of mixed phase clouds (Verheggen et al., 2007). IR and the interstitial particle fraction of the total aerosol in mixed-phase clouds were sampled and analyzed by electron microscopy. As ice-nucleation will often not be initiated by the main component of an individual particle, but also by minor or trace components present as small inclusion or coating, the characterization of the mixing state is of utmost importance. To ensure this detailed analysis of the mixing-state, scanning electron microscopy (SEM) was performed operator controlled. This time-consuming approach is the only way to link ice nucleating capabilities of individual ambient particles with their composition and mixing state.

\subsection{Sampling}

IR and interstitial particle samples from mixed phase clouds were collected with self constructed 2 -stage impactors $(50 \%$ cut off-diameters: $0.1 \mu \mathrm{m}$ and $0.7 \mu \mathrm{m}$ ) operated behind specific inlet systems. The interstitial aerosol was sampled behind an interstitial inlet operated with a PM2 cyclone impactor. The Ice-CVI (Mertes et al., 2007) was used to sample residual particles of small ice particles. In the Ice-CVI supercooled droplets (SDR), ice crystals with $d>20 \mu \mathrm{m}$ and interstitial particles are removed in separate steps. The remaining ice crystals in the size range $5-20 \mu \mathrm{m}$ are then dried and heated to room temperature in order to remove the ice, and the dry ice residuals are sampled for analysis. The system can also be operated in a "droplet-mode", where ice residuals and SDR are deposited (for details see Mertes et al., 2007).

The sampling of IN respectively IR within mixed-phase clouds remains a difficult task with a variety of possible sampling artifacts. ICE-CVI sampling artifacts can have different 
reasons. Possible causes include in general (a) unintentional transmittance of few interstitial particles that could still bias the sampling due to the small amount of ice particle residues, (b) unintentional transmittance of supercooled drops, (c) ice particle break-up inside the Ice-CVI and subsequent sampling of their fragments and (d) particle abrasion from the inner walls of the Ice-CVI inlet due to ice particle impacts. The pre-segregation of interstitial particles is carried out by a conventional CVI (Mertes et al., 2005), which is one part of the Ice-CVI setup. In many airborne applications of this CVI design in pure ice clouds with small ice crystal concentrations it was shown that interstitial particles were successfully suppressed. Moreover, out-of-cloud test samplings were carried out with the Ice-CVI system during the CLACE campaigns, revealing a factor of 100 to 1000 less counts than during ice particle residual samplings in mixed-phase cloud events (Kamphus et al., 2010). Supercooled drops were presegregated in an impactor upstream of the CVI. The impaction plate is made of stainless steel and was equilibrated with the ambient temperature and thus had a temperature of at least $-5^{\circ} \mathrm{C}$ or less. Therefore, the impacting drops will freeze on the impaction plate. The remaining small ice particles also impact at this point, but bounce off without any substantial shattering which is confirmed by a non-critical Weber number (ratio of kinetic to surface energy) determined by Vidaurre and Hallett (2009). Therefore, ice crystals larger than $20 \mu \mathrm{m}$ are removed by a $90^{\circ}$ sampling inlet and a virtual impactor upstream the drop pre-impactor (Mertes et al., 2007), even though this restricts the upper size range of sampled ice particles. Air velocities in front and inside the Ice-CVI inlet system are much smaller compared to airborne measurements, thus particle abrasion is unlikely. The only exception is the wind tunnel where the CVI is situated and the first part of the CVI inlet itself where particle velocities above $100 \mathrm{~m} \mathrm{~s}^{-1}$ need to be reached for a proper size separation by the CVI. But due to the vertical orientation no opposing surfaces exist in this part of the sampling system, where abrasion could occur. This was also checked by additional measurements that did not detect any substantial contribution of particles from the inner walls of the Ice-CVI.

$\mathrm{Ni}$-TEM-grids coated with a formvar foil ( ${ }^{\circledR}$ Plano) were used as sample substrates. In order to obtain an optimized loading of the impaction substrates for individual particle analysis, the sampling time was varied depending on the ambient particle concentrations between 1.5 and $2.5 \mathrm{~h}$ for the interstitial-samples, and between 35 and $56 \mathrm{~h}$ for the IR samples. Sampling of the IR was not performed continuously, as sampling was interrupted during cloud brakes. This may lead to deposition of IR from different air masses on the same substrate. Therefore, a definite assignment of the determined IR to specific air-masses is hindered. Sampling date, sampling duration and temperature are summarized in Table 1.

\subsection{Scanning electron microscopy (SEM)}

The size, chemical composition, morphology and internal mixing state of more than 3600 particles with particulate diameters $\left(d_{\mathrm{P}}\right) \geq 0.7 \mu \mathrm{m}$ from IR and interstitial samples of four cloud events were analyzed by scanning electron microscopy (ESEM, FEI Quanta 200F) and energy-dispersive X-ray microanalysis (EDX, EDAX, Tilburg, The Netherlands). Due to rupture of the formvar foil during sampling, IR and interstitial samples of smaller particles with diameters between $60 \mathrm{~nm}$ and $700 \mathrm{~nm}$ were only received for cloud event 1.

The particles were classified in eight particle groups: silicates, C-O-S particles (complex mixture of carbonaceous material, nitrates and sulphates), sulphates, sea-salt, $\mathrm{Pb}-$ bearing particles, Ca-rich particles, Al-rich particles and complex mixtures (of the previous groups). All particles, which can not be assigned to one of these eight groups were classified as other particles. The classification criteria for the different groups and their most probable source are given in Table 2. Following the classification criteria, aged seasalt (without detectable chlorine content) will be classified as sulphates, and all carbonaceous particles (biological, soot and organics) as C-O-S particles. A more detailed discussion of the characteristics of the particle groups C-O-S, complex mixtures and $\mathrm{Pb}$-bearing particles is given in the results and discussion chapter.

\subsection{Transmission Electron Microscopy (TEM)}

Mineralogical phase composition of selected particles was determined by transmission electron microscopy using a Philips CM20 instrument equipped with an energydispersive $\mathrm{X}$-ray detector. The internal mixing state of $\mathrm{Pb}$ bearing particles was studied in detail by high resolution transmission electron microscopy (HR-TEM) in a Jeol 3010 instrument.

In general, the phase composition is determined by selected area electron diffraction (SAED). However, for particles with such low diameters as encountered in the present study (below $10 \mathrm{~nm}$ ) this technique can not be applied. Alternatively, direct imaging of properly oriented particles provides an access to interplanar spacings and angles. The Fast Fourier Transformation (FFT) of high resolution TEM images yields diffraction patterns which can be indexed for phase determination. For this purpose, the software PIEP (Miehe, 1997) and the ICSD online database were applied.

\section{Results and discussion}

\subsection{Identification of IN}

The relative number abundance of the different particle groups within IR samples and interstitial samples for coarse particles $\left(d_{\mathrm{P}} \geq 0.7 \mu \mathrm{m}\right)$ are given in Table 3 separately for 
Table 1. Sampling parameters for ice residuals (IR) and interstitial samples (Int), collected during CLACE 5 within mixed phase clouds.

\begin{tabular}{llllll}
\hline $\begin{array}{l}\text { cloud } \\
\text { event }\end{array}$ & $\begin{array}{l}\text { particle } \\
\text { fraction }\end{array}$ & $\begin{array}{l}\text { cut off } \\
\text { diameter }[\mu \mathrm{m}]\end{array}$ & $\begin{array}{l}\text { sampling } \\
\text { day }\end{array}$ & $\begin{array}{l}\text { sampling time } \\
{[\mathrm{min}]}\end{array}$ & $\begin{array}{l}\text { temperature } \\
{[\mathrm{K}]}\end{array}$ \\
\hline 1 & IR & $\geq 0.7$ & $10-12 \mathrm{Mar}$ & 2100 & $246-261$ \\
1 & IR & $0.1-0.7$ & $10-12 \mathrm{Mar}$ & 2100 & $246-261$ \\
1 & Int & $0.1-0.7$ & $10 \mathrm{Mar}$ & 125 & $255-258$ \\
1 & Int & $\geq 0.7$ & $10 \mathrm{Mar}$ & 125 & $255-258$ \\
1 & Int & $0.1-0.7$ & $11 \mathrm{Mar}$ & 137 & $253-256$ \\
1 & Int & $\geq 0.7$ & $11 \mathrm{Mar}$ & 137 & $253-256$ \\
2 & IR & $\geq 0.7$ & $26 \mathrm{Feb}-01 \mathrm{Mar}$ & 3344 & $248-260$ \\
2 & Int & $\geq 0.7$ & $26 \mathrm{Feb}$ & 146 & $257-260$ \\
2 & Int & $\geq 0.7$ & $28 \mathrm{Feb}$ & 90 & $252-255$ \\
2 & Int & $\geq 0.7$ & $01 \mathrm{Mar}$ & 154 & $248-254$ \\
3 & IR & $\geq 0.7$ & $02-07 \mathrm{Mar}$ & 2967 & $250-267$ \\
3 & Int & $\geq 0.7$ & $06 \mathrm{Mar}$ & 111 & $251-258$ \\
4 & IR+SDR. & $\geq 0.7$ & $22 \mathrm{Feb}$ & 243 & $259-260$ \\
\hline
\end{tabular}

* Ice residuals (IR) and dried supercooled droplets (SDR).

Table 2. Criteria for classification of particle groups.

\begin{tabular}{|c|c|c|}
\hline particle group & criteria* & description \\
\hline $\mathrm{Pb}$ bearing & $\begin{array}{l}\mathrm{Pb} \text { detected as major or minor component } \\
\text { as well as heterogeneous inclusion }\end{array}$ & $\begin{array}{l}\text { anthropogenic or mixture of anthropogenic } \\
\mathrm{Pb} \text {-component and other particle group }\end{array}$ \\
\hline $\mathrm{C}-\mathrm{O}-\mathrm{S}$ & $\mathrm{C}+\mathrm{O}+\mathrm{S}>90 \%$ and $\mathrm{C}>40 \%$ & secondary aerosols/soot-mixtures \\
\hline silicate & $\mathrm{Si}+\mathrm{Al}+\mathrm{O}>60 \%$ & external silicates (soil) \\
\hline $\mathrm{Al}$ rich & $\mathrm{Al}>50 \%$ and $\mathrm{Si}<5 \%$ & natural or artefact \\
\hline sulfates & $\mathrm{S}>30 \%$ and $\mathrm{C}<40 \%$ & aged sea salt or secondary aerosols \\
\hline sea salt & $\mathrm{Na}>30 \%$ and $\mathrm{Cl}>8 \%$ & sea salt \\
\hline Ca rich & $\mathrm{Ca}>25 \%$ and $\mathrm{Si}+\mathrm{Al}<20 \%$ & soil \\
\hline complex mixtures & $\begin{array}{l}\text { internal mixtures of two or } \\
\text { more other particle groups }\end{array}$ & $\begin{array}{l}75 \% \text { contain silicates and/or metal } \\
\text { oxides }(\mathrm{Fe}, \mathrm{Ti}) \text { as main component }\end{array}$ \\
\hline other & not in the above mentioned classes & - \\
\hline
\end{tabular}

* X-ray intensity of elements relative to the sum of net counts of all elements with $5<Z<83$.

the different cloud events. For fine particles $\left(0.1 \leq d_{\mathrm{P}} \leq\right.$ $0.7 \mu \mathrm{m})$, the relative number abundance of the different particles groups is listed in Table 4. Due to the low IN concentration, the sampling times for IR samples were rather long (about 2 days, Table 1) in order to obtain a sufficient loading of the sampling substrates. In contrast, for interstitial samples a sampling duration of approximately $2 \mathrm{~h}$ was applied. Consequently, often several interstitial samples but only one IR sample were received for the same cloud event. Scanning electron microscopy and energy-dispersive X-ray microanalysis revealed that different interstitial samples from the same cloud event have almost identical composition. Therefore, the particle group number abundances of the IR samples are compared with an average particle group number abundance of the different interstitial samples in Tables 3 and 4.

Not all particles found in the IR samples are necessarily IN, because it cannot be expected that separation within the Ice-CVI has an $100 \%$ efficiency. All instrumental tests showed that the different hardware parts of the sampler, responsible for the separation of larger ice crystals, SDR and the interstitial aerosol are working with high efficiency (Mertes et al., 2007). In addition, small ice crystals that originate from rime splintering, fragmentation during collisions of ice crystals and shattering of droplets during freezing may also be present in the IR samples. However, these ice crystals are expected to be predominantly smaller than $\sim 100 \mathrm{~nm}$ (Mertes et al., 2007; Kamphus et al., 2010), and are, thus, not collected in the present study.

Furtheron, ice crystals can scavenge other particles, which will be present in the IR fraction besides the original IN. To minimize this effect only small ice crystals are sampled.

Nevertheless, because of all these reasons and the fact that within a mixed-phase cloud the IN fraction is very small $\left(\leq 10^{-5}\right.$ during CLACE5; Mertes et al., 2007) the risk of 
Table 3. Relative particle group number abundance [\%] of the different particle groups of ice residuals (IR) and interstitial samples (Int) for four cloud events $\left(d_{\mathrm{P}} \geq 0.7 \mu \mathrm{m}\right)$.

\begin{tabular}{|c|c|c|c|c|c|c|c|}
\hline & \multicolumn{2}{|c|}{ cloud event 1} & \multicolumn{2}{|c|}{ cloud event 2} & \multicolumn{2}{|c|}{ cloud event 3} & \multirow{2}{*}{$\begin{array}{c}\text { cloud event } 4 \\
\text { IR }+ \text { SDR }\end{array}$} \\
\hline & IR & Int & IR & Int & IR & Int & \\
\hline $\mathrm{Pb}$ bearing & 19 & 0 & 9 & 1 & 24 & 1 & 2 \\
\hline $\mathrm{C}, \mathrm{O}, \mathrm{S}$ & 27 & 7 & 22 & 17 & 17 & 9 & 21 \\
\hline silicate & 14 & 32 & 19 & 27 & 14 & 19 & 9 \\
\hline Al-rich & 0 & 4 & 0 & 2 & 5 & 1 & 7 \\
\hline sulfates & 11 & 21 & 24 & 42 & 11 & 44 & 28 \\
\hline sea-salt & 10 & 29 & 7 & 4 & 6 & 23 & 11 \\
\hline Ca-rich & 4 & 4 & 6 & 4 & 7 & 1 & 4 \\
\hline complex mixtures & 10 & 2 & 9 & 1 & 15 & 0 & 7 \\
\hline other & 4 & 1 & 4 & 3 & 0 & 1 & 11 \\
\hline$N_{\text {total }}$ & 617 & 512 & 502 & 447 & 718 & 277 & 621 \\
\hline
\end{tabular}

$N_{\text {total }}=$ total number of analyzed particles; $*$ ice residuals (IR) and dried supercooled droplets (SDR).

sampling artefacts cannot be completely excluded. Therefore, only particle groups, which are significantly enriched (at least by a factor of two) in the IR samples compared to the interstitial samples are interpreted as IN (a similar definition of IN was used previously by Hoose, 2009).

For particles with diameters above $700 \mathrm{~nm}$ (Table 3), the dominant particle groups in the interstitial samples are C-O-S particles (complex secondary aerosol particles consisting of a mixture of sulfates, nitrates, organics and sometimes identified soot inclusions), pure sulphates, sea-salt and silicates. For smaller particles $(60-700 \mathrm{~nm})$ of the interstitial samples, the two secondary aerosol particle groups C-O-S and pure sulfates are dominating alone ( $>90 \%)$. In general, this composition is typical for a rural or urban background aerosol in Central Europe (e.g., Ebert et al., 2002a, 2004; Vester et al., 2007).

The variable sea-salt abundance for the different cloud events can be directly related to the air mass history. The high amounts of sea salt and aged sea salt (classified in the sulphate group) during cloud event 1 and 3 are due to the direct transport of the air masses from the Atlantic in contrast to cloud events 2 and 4 with air masses from Central/Eastern Europe (backtrajectories were calculated using the Hysplit model (Draxler and Rolph, 2003).

The IR samples are characterized by high abundances of $\mathrm{C}-\mathrm{O}-\mathrm{S}$ particles, $\mathrm{Pb}$-bearing particles, silicates, pure sulfates and complex mixtures (Tables 3 and 4). In order to show enrichments within the IR samples relative to interstitial samples, average particle group abundances are displayed in Fig. 1 for $d_{\mathrm{P}} \geq 0.7 \mu \mathrm{m}$. Results from cloud event 4 were not considered here, as the Ice-CVI was operated in the "droplet"-mode during this event. Due to the fact, that the supercooled droplets are not removed in the "droplet"-mode, the relative abundance of sulphate and secondary particles increases here in comparison to the pure IR samples (cloud event 1-3).
Table 4. Relative particle group number abundance [\%] of the different particle groups of ice residuals (IR) and interstitial (Int) samples $\left(0.1 \leq d_{\mathrm{P}} \leq 0.7 \mu \mathrm{m}\right)$.

\begin{tabular}{lrr}
\hline & \multicolumn{2}{c}{ cloud event 1} \\
particle group & IR & Int \\
\hline Pb bearing & 20 & 1 \\
$\mathrm{C}, \mathrm{O}, \mathrm{S}$ & 30 & 20 \\
silicate & 12 & 4 \\
Al rich & 10 & 0 \\
sulfates & 14 & 71 \\
sea salt & 6 & 0 \\
Ca rich & 2 & 1 \\
complex mixtures & 2 & 2 \\
other & 3 & 1 \\
$N_{\text {total }}$ & 1162 & 2313 \\
\hline
\end{tabular}

$N_{\text {total }}=$ total number of analyzed particles.

Pronounced enrichments within the IR fraction $\left(d_{\mathrm{P}} \geq\right.$ $0.7 \mu \mathrm{m})$ were observed for the three groups of C-O-S particles (from 11 to $22 \%$ ), complex mixtures (from 2 to $14 \%$ ) and above all $\mathrm{Pb}$ bearing particles (from 0.7 to $18 \%$ ). The characteristics of these groups are discussed in detail in Sect. 3.2. In cloud event 1 , the fine IR $\left(0.1 \leq d_{\mathrm{P}} \leq 0.7 \mu \mathrm{m}\right)$ have a similar composition as the coarse IR. The only difference was a higher abundance of aluminium rich particles (aluminium oxides, mostly mixed with $\mathrm{Ca}$ and $\mathrm{S}$ ) and a lower abundance of the complex mixtures in the small IR fraction.

Enrichment of metallic particles (e.g. Al, Ti) in the IR fraction was also observed during CLACE6 by Kamphus et al. (2010). Aluminium rich particles (interpreted as propellant combustion residuals from rockets) were found to be efficient IN (Parungo and Allee, 1978). It is interesting to note that in this paper aluminium oxide particles mixed with 


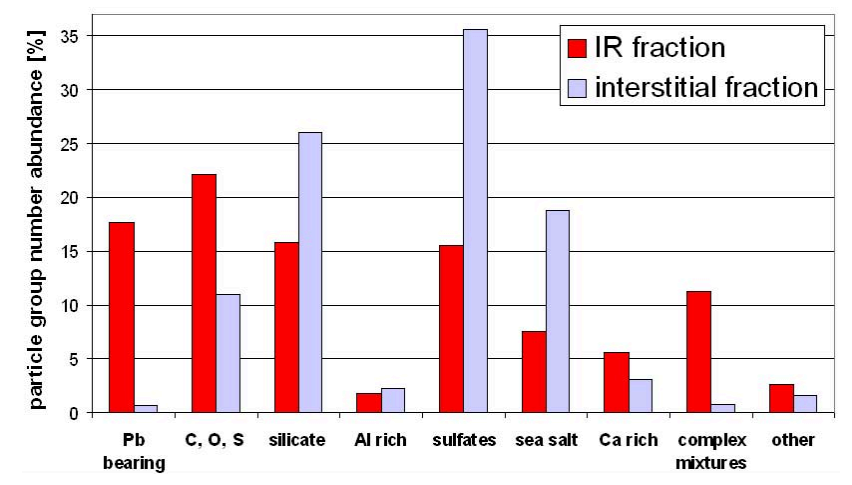

Fig. 1. Average particle group number abundance within ice residuals (IR) and interstitial samples within mixed phase clouds $\left(d_{\mathrm{P}} \geq\right.$ $0.7 \mu \mathrm{m})$ for cloud events $1-3(\mathrm{C}, \mathrm{O}, \mathrm{S}=$ soot/secondary material mixtures; $3 / 3$ of the complex mixtures contain silicates and/or metal oxides).

$\mathrm{Ca}$ and $\mathrm{S}$ were identified to be the most efficient IN (not the more abundant pure $\mathrm{Al}_{2} \mathrm{O}_{3}$ particles). This observation is in agreement with the observed enrichment of Al-rich particles with complex mixing-state found in the fine IR fraction of our study.

All other particle groups are depleted or show only minor enrichments in the IR samples (Fig. 1). The most pronounced depletion in the coarse $(\geq 0.7 \mu \mathrm{m})$ IR is observed for external silicates (from 26 to 16\%), and for the soluble particle groups sulphate (from 36 to $15 \%$ ) and sea-salt (from 19 to $8 \%$ ). This is not surprising for the two latter groups, as sulfates and sea salt particles are generally regarded as inefficient IN (Wallace and Hobbs, 2006). The depletion of external silicates in the IR samples is somewhat surprising as many silicate minerals (especially clay minerals) are known to be efficient IN (e.g., Roberts and Hallet, 1968; Zuberi et al., 2002). However, the ice nucleation efficiency of silicate minerals is highly variable (e.g., Zimmermann et al., 2008). As the phase composition of the particles was not determined, we cannot rule out the possibility that the most efficient silicate IN (clay minerals) were only present at low concentrations among external silicates. Beside external grains, silicates are an important constituent of complex mixtures and $\mathrm{Pb}$ bearing particles (see below) which are both strongly enriched in the IR fraction. Thus it is found that silicates are an important IN component at the Jungfraujoch station which is in agreement with the observations of Kamphus et al. (2010).

\subsection{Characteristics of IN}

\subsubsection{C-O-S group (complex mixtures of organics, sulfates, and nitrates)}

Particles in the C-O-S group are internal mixtures of the secondary components: organics, sulfates, and nitrates. In some of these particles we have also identified primary soot inclu- sions. These complex mixtures are a very common particle type and are often found in the fine-mode of urban or urban influenced aerosol samples. These complex secondary mixtures often incorporate soot inclusions (e.g., Murphy et al., 2006; Vester et al., 2007; Adachi et al., 2010).

Freshly emitted unaltered soot particles can be clearly identified by SEM analysis on base of their highly characteristic morphology. Even small soot agglomerates $(<100 \mathrm{~nm})$ on the surface of other particles can be identified unambiguously. The soot inclusions, which were detected in this study within the $\mathrm{C}, \mathrm{O}, \mathrm{S}$ particles exhibit a complex mixing state and are highly compacted (Fig. 2) indicating advanced atmospheric aging (Weingartner et al., 1997). The soot identification by SEM was verified by high resolution transmission electron microscopic studies which showed nano-crystalline graphitic layers. This typical soot microstructure was observed in several previous papers (e.g. Posfai et al., 1999; Wentzel et al., 2003).

The occurence of soot in the IR fraction at the Jungfraujoch is in agreement with the findings of Cozic et al. (2008), who performed black carbon (BC) bulk measurements of IR samples and the total aerosol during CLACE5. They found an enrichment of the relative BC abundance from $9 \%$ for the total aerosol to $27 \%$ in the IN samples (mass concentration). A similar enrichment of BC (4 to 18 mass\%) was found during CLACE3 (February-March 2004) by Mertes et al. (2007). In contrast, Kamphus et al. (2010) found similar contents of carbon-containing particles (sulfates with strong carbon/organic signal) within the IR and the background aerosol ( $\sim 25 \%$ by number) during CLACE6 (FebruaryMarch 2007). Independent of the question how large the BC content within the $\mathrm{C}, \mathrm{O}, \mathrm{S}$ group is in detail (this question cannot be answered quantitatively by SEM and EDX analysis) these mixtures of insoluble organic material, soot and sulfates are one major IR component, what is in agreement with prior IR studies within mixed phase clouds (Phillips et al., 2008 and references therein).

Based on the morphological information, none of the carbonaceous particulate components could be assigned as biological (a total of $879 \mathrm{C}-\mathrm{O}-\mathrm{S}$ particles from the whole size range was analyzed in detail by individual particle analysis). Externally mixed biological material as plant debris, pollen or spores can be easily identified by SEM on base of their morphology and characteristic minor elements (Ebert et al., 2000c). However, in such complex internal mixtures as encountered during CLACE 5 detection of biological components is hindered. Therefore, we cannot exclude the presence of thin bacteria films or bacteria agglomerates. There are several bacteria strains identified, which can act as IN (Maki et al., 1974). As many soil particles presumably carry small amounts of bacteria, the importance of this species for ice nucleation is discussed for a long time (e.g., Schnell and Vali, 1972). Since living cells contain liquid water and the freezing of this cell solution is usually lethal for the organism (Mazur, 1984), most other biological material have 
no special IN-capabilities. Some freeze-tolerant organisms (herbaceous plants, interdial molluscs) have effective IN outside the cells, ensuring extra-cellular freezing close to $0{ }^{\circ} \mathrm{C}$ (Szymer and Zawadzki, 1997).

\subsubsection{Complex mixtures (mainly silicate and metal oxide mixtures)}

The majority of all particles identified as IN within mixed phase clouds at the Jungfraujoch station exhibit a complex internal mixing state. Mixtures with a dominant major element (e.g., Al, C) or a highly characteristic minor element $(\mathrm{Pb})$ were classified in separated groups. All other internal mixtures are summarized in the group of complex mixtures.

The complex internal mixing state of the ice residuals can be explained by the reactive environment of a mixed phase cloud. Besides particle formation, condensation and coagulation processes, which can also be observed outside clouds, a variety of additional particle modifications under participation of the water and/or ice phase can alter the morphology, chemical composition and mixing-state. In literature, residues of evaporated droplets and sublimated ice particles are described to be very effective IN (Beard, 1992; Rosinski, 1995). The reason for the enhanced IN efficiency of such complex internal mixtures remains unclear.

Another reason for the complex mixing state of the ice residuals could be scavenging of the small ice crystals, sampled by the ICE-CVI. In this case the complex mixing state of the IR would be an artefact and no characteristic of the original IN. Because of the small size of the sampled ice crystals we assume that scavenging plays only a minor role. Nevertheless, taking the results of this study and ignoring minor compounds of each individual IR as possible scavenged material (i.e. considering only the main component) the same particle groups (" $\mathrm{C}, \mathrm{O}, \mathrm{S}$ "/“ $\mathrm{Pb}$-containing" and the main components of the group "complex mixtures"-silicates and metal oxides) are identified as original IN.

In the present study 428 complex mixtures in the different IR samples were found. Silicates (mostly mixed with carbonaceous material) are the most abundant major component within these mixtures (50\% of the mixtures contain silicates as major component). Beside silicates, metal oxides (predominantly Fe-oxides, but also smaller amounts of $\mathrm{Al}-, \mathrm{Zn}$ - and Ti-oxides) were found to be the main component in around $25 \%$ of the complex mixtures (also described by Chen et al., 1998). The remaining $25 \%$ are internal mixtures of 2 or more components (including sulfates and sea-salt), listed in Table 3. These complex mixtures were also described in prior IR investigations within mixed phase clouds. In these studies these particles were either classified as "other" or were classified according to their main component as "silicates" or "metallic" (e.g. Chen et al., 1998; Phillips et al., 2008).

During CLACE 3 and CLACE 4, where Pb-bearing particles were only observed in much lower quantity, these mix-
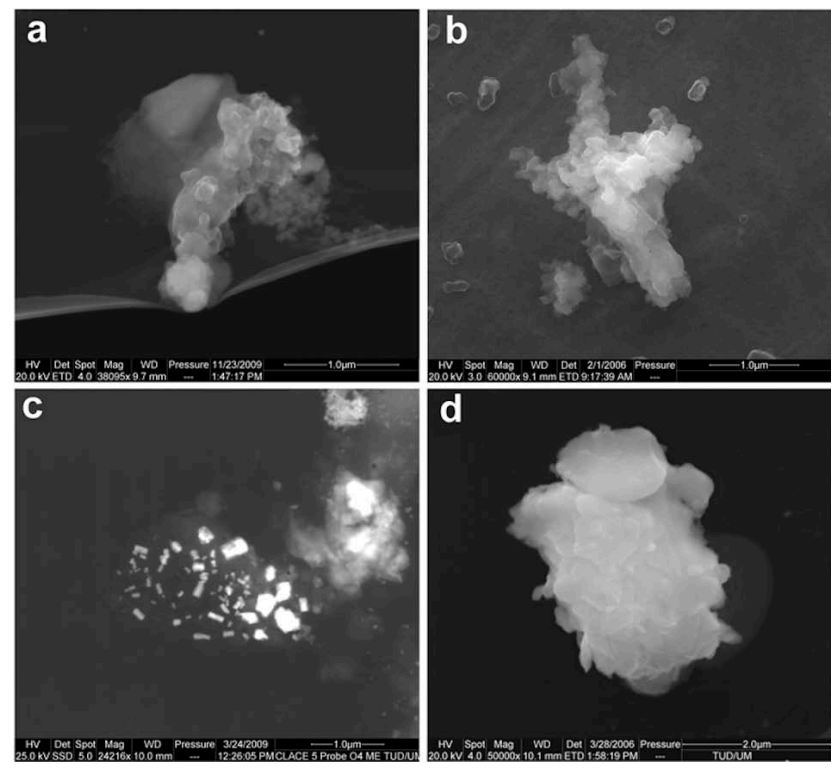

Fig. 2. Secondary electron image of (a) C-O-S particle, (b) Al-rich particle; (c) Pb-bearing particle (bright inclusions) and (d) complex internal mixture (silicate/sulfate).

tures of silicates and carbonaceous material showed the highest enrichment in the IR fraction of all particle groups (Ebert et al., 2006). The detailed organic composition of the carbonaceous material is not known. However, in different heating and deliquescence experiments with particles from CLACE 3 and 4 in the environmental scanning electron microscope (Ebert et al., 2002b) it was shown that the carbonaceous material in these mixtures is non-hygroscopic and low-volatile, pointing to a black carbon or resin like material (Ebert et al., 2006). Silicate/carbonaceous mixtures were also detected during CLACE 1 by a transportable laser mass spectrometer (LAMPAS2) and could be correlated with high absorption pointing to a black carbon (Hinz et al., 2005).

\subsubsection{Pb bearing particles}

With an average particle group number abundance of $18 \%$ in the IN-fraction, the $\mathrm{Pb}$ bearing particles are enriched by a factor of 25 (!) relative to the interstitial fraction $(0.7 \%)$. In contrast to the other particle groups, the definition of the " $\mathrm{Pb}$ bearing" group also includes particle with minor amounts of this element. All particles with detectable $\mathrm{Pb}$ concentrations in an EDX spot-measurement at any place of an individual particle were classified as " $\mathrm{Pb}$ bearing". Electron micrographs of such $\mathrm{Pb}$-bearing particles are shown in Fig. 3. During the same experiment, a high abundance of $\mathrm{Pb}$ bearing particles in the IR fraction (32\% in terms of number) was also observed by single particle mass spectrometry (Cziczo et al., 2009). The higher value obtained from mass spectrometry compared to energy-dispersive $\mathrm{X}$-ray microanalysis can be easily explained by the lower detection limit. 

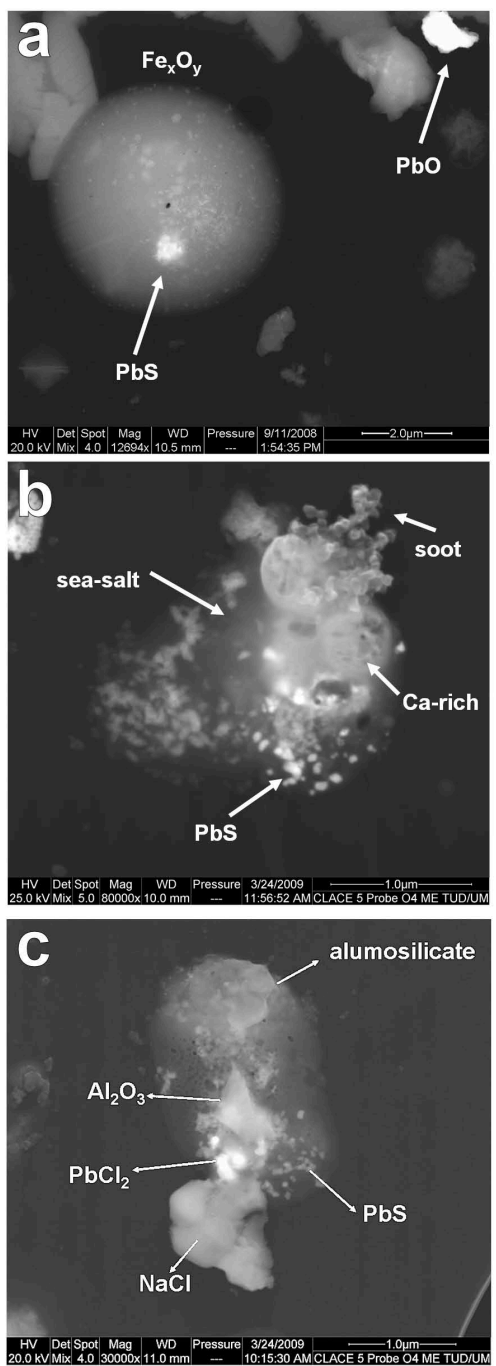

Fig. 3. Mixed secondary/backscatter electron images of Pb-bearing particles.

In the four cloud events investigated, between 0 and $22 \%$ of all $\mathrm{Pb}$ bearing particles were external $\mathrm{Pb}$ rich particles (Fig. 3a). External particles were identified by energydispersive X-ray microanalysis as lead oxides or lead chlorides. The majority of all particles classified as " $\mathrm{Pb}$-bearing" contains only small $\mathrm{Pb}$ inclusions respectively small $\mathrm{Pb}$ grains at the surface (Fig. 3). The fact that most $\mathrm{Pb}$ bearing particles contain this element only in minor or trace concentrations was also observed for total aerosol samples at a variety of locations by Murphy et al. (2007).

From two-dimensional TEM-bright field images the volume fraction of the lead-rich inclusions was calculated assuming spheres with equivalent projected areas. The volume fraction of the lead-rich inclusions is mostly in the range of $0.5-8 \%$. The $\mathrm{Pb}$-components are found either embedded in or agglomerated with almost all particle groups observed in this study (Table 5). Most abundant "matrix" particles were
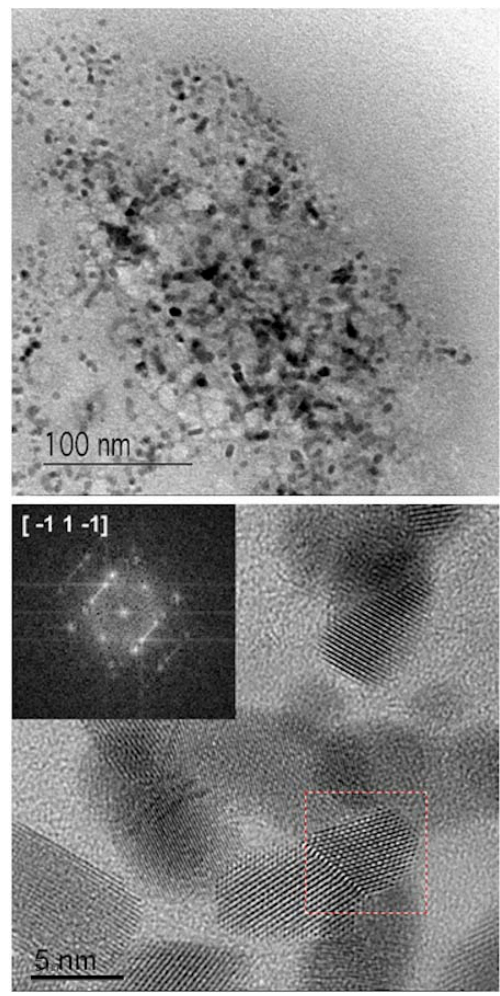

Fig. 4. (a) TEM bright field image of PbS-inclusions in a sulphate particle, and (b) HR-TEM bright field image and pseudo-diffraction pattern of the inclusions.

silicates and sea salt/sulphate-mixtures (Fig. 3b, c). ESEM observations show that there is often more than one $\mathrm{Pb}$-rich inclusion within or more than one coagulate on the surface of an individual particle (Fig. 3c). The detailed internal structure and the mineralogical phase of the $\mathrm{Pb}$-inclusions was determined by HR-TEM. High resolution TEM images showed that most of the some hundred $\mathrm{nm}$ large $\mathrm{Pb}$-rich inclusions are composed of a large number of much smaller primary $\mathrm{Pb}$-rich particles (Fig. 4a). The size-distribution of the primary $\mathrm{Pb}$-rich particles is very narrow with a maximum at a geometric diameter between 3 and $8 \mathrm{~nm}$.

From the HR-TEM bright field images of the Pb-rich inclusions pseudo-diffraction pattern were calculated by fast Fourier transformation to determine the phase composition. The majority of all analyzed primary $\mathrm{Pb}$-rich particles could be identified as $\mathrm{PbS}$ (Fig. 4b), some primary particles are elemental $\mathrm{Pb}$. The small primary $\mathrm{Pb}$-rich particles are coagulated onto pre-existing particles of all observed particle groups in the IR fraction. Coagulation of small $\mathrm{Pb}$-rich particles onto the surface of other particles in the urban environment was observed in previous studies (Utsunomiya et al., 2004; Choel et al., 2006). Condensation of gaseous $\mathrm{Pb}$ compounds is less probable as they are only present in very low concentrations (Shotyk and Le Roux, 2005). After banning of tetra-ethyl lead from automotive petrol in 1980, the 
Table 5. Relative abundance of homogeneous $\mathrm{Pb}$-rich particles and particles with $\mathrm{Pb}$-inclusions within the group ,Pb-bearing particles” in IR samples.

\begin{tabular}{lrrr}
\hline & \multicolumn{3}{c}{ abundance of Pb bearing particles [\%] } \\
\cline { 2 - 4 } & $\begin{array}{r}\text { cloud } \\
\text { event } 1\end{array}$ & $\begin{array}{r}\text { cloud } \\
\text { event 2 }\end{array}$ & $\begin{array}{r}\text { cloud } \\
\text { event 3 }\end{array}$ \\
\hline homogeneous & 14 & 22 & 10 \\
Pb-rich particles & & & \\
$P b$ inclusion within: & 25 & 43 & 42 \\
silicate & 12 & 0 & 14 \\
C, O, S & 19 & 28 & 16 \\
sea salt/sulfate & 3 & 0 & 5 \\
Ca-rich & 0 & 0 & 3 \\
metal oxides & 2 & 0 & 9 \\
Al rich & 25 & 7 & 2 \\
other & 355 & 46 & 175 \\
$N_{\text {total }}$ & 20 & 9 & 24 \\
abundance in IR samples* & & & \\
\hline
\end{tabular}

$N_{\text {total }}=$ total number of analyzed Pb-bearing particles;

* relative abundance [\%] of Pb-bearing particles in IR sample.

lead concentration within atmospheric aerosols has dropped drastically (e.g. Ebert et al., 2000; EPA, 2002). Today, the dominant sources for $\mathrm{Pb}$-rich particles are light aviation fuel (which still contains tetra-ethyl lead), emissions from coal combustion and lead smelters (Murphy et al., 2007). In contrast to previous CLACE campaigns, lot of helicopter traffic occurred in the direct vicinity of the Jungfraujoch station during CLACE 5. Indeed, Pb-rich particle were found at a much higher abundance during CLACE 5. Alternatively, lead smelters could also be the source of the lead compounds observed in our field campaign. The same $\mathrm{Pb}$ species as observed at the Jungfraujoch station $\left(\mathrm{PbCl}_{2}, \mathrm{~Pb}, \mathrm{PbS}\right.$ and $\left.\mathrm{PbO}\right)$ were found in the vicinity of a lead smelter (Batonneau et al., 2004).

In our experiment, $\mathrm{PbO}, \mathrm{PbCl}_{2}, \mathrm{~Pb}$ and $\mathrm{PbS}$ were the only $\mathrm{Pb}$ species observed. However, $\mathrm{PbI}_{2}$ is the only atmospheric relevant lead compound for which high IN efficiency was demonstrated up to now (Mason and Hallet, 1957). The role of lead iodine from automobile exhausts for ice nucleation is discussed controversely. According to Schäfer (1966), an increased number of IN downwind of automobile roads can be attributed to lead iodine (e.g. Schäfer, 1966). In contrast, Grant and Corrin (1973) pointed out that the formation of lead iodine in automobile exhaust is thermodynamically unfavourable. This view was opposed by Langer (1970) and Reischel and Vali (1975) who suggested an important role of $\mathrm{PbO}$ in cooperation with nitrogen oxides or ammonium iodine leading to formation of $\mathrm{PbI}_{2}$. As we have not determined $\mathrm{PbI}_{2}$ in any of the $\mathrm{Pb}$-bearing particles, even by $\mathrm{HR}$ TEM investigations on a nm-scale, it is concluded that the detected $\mathrm{Pb}$ species $\left(\mathrm{PbO}, \mathrm{Pb}, \mathrm{PbS}\right.$ or $\mathrm{PbCl}_{2}$ ) increase the IN capabilities of a mixed particle. As these $\mathrm{Pb}$ species have no increased IN efficiency as external mixture, this effect must be attributed to the mixing state. Our conclusion is confirmed by recent laboratory experiments (Cziczo et al., 2009). In these experiments, kaolinite particles doped with $1 \% \mathrm{PbSO}_{4}$ showed an increased IN capability in contrast to the externally mixed kaolinite particles, although the pure $\mathrm{PbSO}_{4}$ particles were inefficient IN.

\section{Conclusions}

1. The combination of Ice-CVI sampling and electron microscopy (SEM and TEM) of the ice residuals enables the identification and detailed physico-chemical characterization (size, morphology, shape, chemical composition, mineralogy and mixing state) of IN within mixed phase clouds. Reliable IN identification can be reached by determination of the enrichment of a given particle group in IR samples relative to the interstitial aerosol.

2. During CLACE 5, particle groups significantly enriched in IR samples include $\mathrm{Pb}$-bearing particles, $\mathrm{C}-\mathrm{O}-\mathrm{S}$ particles and complex mixtures. Other particle groups found in the IR samples (silicates, sulfates, sea salt, Ca-rich particles) cannot be assigned unambiguously as IN. All particle groups interpreted as IN show a complex mixing state.

3. Most IN identified at the Jungfraujoch station are internal mixtures containing anthropogenic components (either as main or minor constituent). For example, silicate/carbonaceous material and silicate/sulfate mixtures are more enriched in the IR fraction as pure silicates. Therefore, it appears that admixture of anthropogenic components increases the IN efficiency within mixed phase clouds at the Jungfraujoch station. The mixing state seems to be a key parameter for the ice nucleation behaviour that cannot be predicted from the separate components. Consequently, future laboratory experiments should expand their scope from pure external mixtures or pure components with coatings to the more complex internal mixing observed in natural aerosols.

Acknowledgements. Financial support by the German Science Foundation (Sonderforschungsbereich 641 "The tropospheric ice phase") and the grant 939/8-2, the European Community Research Infrastructure Action (FP6 Structuring the European Research Area Programme, EUSAAR Contract No. RII3-CT-2006-026140) and MeteoSwiss (in the framework of the Global Atmosphere Watch program) is gratefully acknowledged. We also thank the International Foundation High Altitude Research Stations Jungfraujoch and Gornergrat (HFSJG) for the opportunity to perform experiments on the Jungfraujoch.

Edited by: O. Möhler 


\section{References}

Adachi, K., Chung, S. H., and Buseck, P. R.: Shapes of soot aerosol particles and implications for their effects on climate, J. Geophys. Res., 115, D15206, doi:10.1029/2009JD012868, 2010.

Batonneau, Y, Bremard, C., Gengembre, L., Laureyns, J., Le Maguer, A., Le Maguer, D., Perdrix, E., and Sobanska, S.: Speciation of PM10 sources of airborne nonferrous metals within the 3-km zone of lead/zinc smelters, Environ. Sci. Technol., 38, 5281-5289, 2004.

Beard, K. V.: Ice initiation in warm-base convective clouds: An assessment of microphysical mechanisms, Atmos. Res., 28, 125152, 1992.

Bingemer, H. G., Klein, H., Ebert, M., Haunold, W., Bundke, U., Herrmann, T., Kandler, K., Müller-Ebert, D., Weinbruch, S., and Curtius, J.: Enhanced atmospheric ice nuclei in the Eyjafjallajökull volcanic ash plume over central Europe, in review, 2011.

Cantrell, W. and Heymsfield, A.: Production of ice in tropospheric clouds, Bull. Am. Meteorol. Soc., 86, 795-807, 2005.

Chen, Y., Kreidenweis, S. M., McInnes, L. M., Rogers, D. C., and DeMott, P. J.: Single particle analyses of ice nucleating aerosols in the upper troposphere and lower stratosphere, Geophys. Res. Lett., 25, 1391-1394, doi:10.1029/97GL03261, 1998.

Choel, M., Deboudt, K., Flament, P., Lecornet, G., Perdrix, E., and Sobanska, S.: Fast evolution of tropospheric $\mathrm{Pb}-$ and $\mathrm{Zn}$-rich particles in the vicinity of a lead smelter, Atmos. Environ., 40, 4439-4449, 2006.

Cozic, J., Mertes, S., Verheggen, B., Cziczo, D. J., Gallavardin, S.J., Walter, S., Baltensperger, U., and Weingartner, E.: Black carbon enrichment in atmospheric ice particle residuals observed in lower tropospheric mixed phase clouds, J. Geophys. Res., 113, D15209, doi:10.1029/2007JD009266, 2008.

Cziczo, D. J., Murphy, D. M., Hudson, P. K., and Thomson, D. S.: Single particle measurements of the chemical composition of cirrus ice residue during crystal-face, J. Geophys. Res., 109, D04201, doi:10.1029/2003JD004032, 2004.

Cziczo, D. J., Stetzer, O, Worringen, A., Ebert, M., Weinbruch, S., Kamphus, M., Gallavardin, S. J., Curtius, J., Bormann, S., Froyd, K. D., Mertes, S., Möhler, O., and Lohmann, U.: Inadvertent Climate Modification Due to Anthropogenic Lead, Nature Geosci., 2, 333-336, 2009.

DeMott, P. J., Cziczo, D. J., Prenni, A. J., Murphy, D. M., Kreidenweis, S. M., Thomson, D. S., Borys, R., and Rogers, D. C.: Measurements of the concentration and composition of nuclei for cirrus formation, Proc. Natl. Acad. Sci. USA, 100, 14655-14660, 2003a.

DeMott, P. J., Sassen, K., Poellot, M. R., Baumgardner, D., Rogers, D. C., Brooks, S. D., Prenni, A. J., and Kreidenweis, S. M.: African dust aerosols as atmospheric ice nuclei Geophys. Res. Lett., 30, 1732, doi:10.1029/2003GL017410, 2003 b.

Draxler, R., and Rolph, G.D.: HYSPLIT (HYbrid Single-Particle Lagrangian Integrated Trajectory) Model access via NOAA ARL READY Website http://www.arl.noaa.gov/ready/hysplit4.htmlS, NOAA Air Resources Laboratory, Silver Spring, MD, 2003.

Durant, A. J., Shaw, R. A., Rose, W. I., Mi, Y. and Ernst, G. G. J.: Ice nucleation and overseeding of ice in volcanic clouds, J. Geophys. Res., 113, D09206, doi:10.1029/2007JD009064, 2008.

Eastwood, M. L., Cremel, S., Gehrke, C., Girard, E., and Bertram, A. K.: Ice nucleation on mineral dust particles: Onset conditions, nucleation rates and contact angles, J. Geophys. Res., 113,
D22203, doi:10.1029/2008JD010639, 2008.

Ebert, M., Weinbruch, S., Rausch, A., Gorzawski, G., Hoffmann, P., Wex, H., and Helas, G.: The complex refractive index of aerosols during LACE 98 as derived from the analysis of individual particles, J. Geophys. Res., 107(D21), 8121, doi:10.1029/2000JD000195, 2002a.

Ebert, M., Inerle-Hof, M., and Weinbruch, S.: Environmental scanning electron microscopy as a new technique to determine the hygroscopic behaviour of individual aerosol particles, Atmos. Environ., 36, 5909-5916, 2002b.

Ebert, M., Weinbruch, S., Hoffmann, P., and Ortner, H. M.: Chemical Characterization of North Sea Aerosol Particles by Total Reflection X-Ray Fluorescence Analysis and High-Resolution Scanning Electron Microscopy, J. Aerosol Sci., 31, 613-632, 2000c.

Ebert, M., Weinbruch, S., Hoffmann, P., and Ortner, H. M.: The chemical characterization and complex refractive index of rural and urban influenced aerosols determined by individual particle analysis, Atmos. Environ., 38, 6531-6545, 2004.

Ebert, M., Worringen, A., Inerle-Hof, M., Benker, N., and Weinbruch, S.: Identification of the ice forming fraction of the atmospheric aerosol in mixed-phase clouds by environmental scanning electron microscopy, Activity Report 2005/2006 International Foundation High Altitude Research Stations JG, Bern Switzerland, 105-112, 2006.

Eidhammer, T., DeMott, P. J., and Kreidenweis, S. M.: A comparison of heterogeneous ice nucleation parameterizations using a parcel model framework, J. Geophys. Res., 114, D06202, doi:10.1029/2008JD011095, 2009.

Environmental Protection Agency. Latest findings on National Air Quality, 2002 Status and Trends (US Environmental Protection Agency, 2003); available at: http://www.epa.gov/air/airtrends/ aqtrnd02/2002_airtrends_final.pdf, 2002.

Grant, L. O. and Corrin, M. L.: Raw and iodine-treated automobile exhaust as a source of ice nuclei, J. Weather Modification, 5, 238-248, 2001.

Hinz, K.-P., Trimborn, A., Weingartner, E., Henning, S., Baltensberger, U., and Spengler, B.: Aerosol single particle composition at the Jungfraujoch, Aerosol Sci., 36, 123-145, 2005.

Hobbs, P. V., Fullerton, M., and Bluhm, G.: Ice nucleus "storms" in Hawaii, Nature Physical Science, 230, 90-91, 1971.

Hoose, C.: Biological Ice formation, Nature Geosci., 2, 385-386, 2009.

Isono, K., Komabayasi, M., and Ono, A.: Volcanoes as a sources of atmospheric ice nuclei, Nature, 183, 317-319, 1959.

Kamphus, M., Ettner-Mahl, M., Klimach, T., Drewnick, F., Keller, L., Cziczo, D. J., Mertes, S., Borrmann, S., and Curtius, J.: Chemical composition of ambient aerosol, ice residues and cloud droplet residues in mixed-phase clouds: single particle analysis during the Cloud and Aerosol Characterization Experiment (CLACE 6), Atmos. Chem. Phys., 10, 8077-8095, doi:10.5194/acp-10-8077-2010, 2010.

Langer, G.: A study of automobile exhaust as a source of ice nuclei, Preprints of the second National Conference on Weather Modification, American Meteorological Society, Boston, Massachusetts, 242-243, 1970.

Lohmann, U. and Diehl, K.: Sensitivity studies of the importance of dust ice nuclei for the indirect aerosol effect on stratiform mixed phase clouds, J. Atmos. Sci., 63(3), 968-982, 2006. 
Lohmann, U. and Feichter, J.: Global indirect aerosol effects: a review, Atmos. Chem. Phys., 5, 715-737, doi:10.5194/acp-5-7152005, 2005.

Maki, L. R., Galyan, E. L., Chang-Chien, M., and Caldwell, D.: Ice nucleation induced by Pseudomonas syringae, Appl. Microbiol., 28, 456-459, 1974.

Mason, B. J.: The Physics of Clouds, Clarendon Press, Oxford, 660 pp., 1971.

Mason, B. J. and Hallet, J.: Ice-Forming Nuclei, Nature, 179, 357359, 1957.

Mazur, P.: Freezing of living cells: Mechanisms and implications, Amer. J. Physiol. Cell Physiol., 16, C125-C142, 1984.

Mertes, S., Verheggen, B., Walter, S., Ebert, M., Conolly, P., Weingartner, E., Schneider, J., Bower, K., Weinbruch, S., Cozic, J., and Heintzenberg, J.: Counterflow virtual impactor based collection of small ice particles in mixed-phase clouds for the physicochemical characterisation of tropospheric ice nuclei: sampler description and first case study, Aerosol Sci. Technol., 41, 848-864, 2007.

Miehe, G.: Algorithmen mit geringem Informationsbedarf zur Phasenanalyse und Gitterkonstantenbestimmung aus Elektronenbeugungsdaten, Ber. Dtsch. Mineral. Ges. Beih. Z. Eur. J. Mineral, 9, 250, 1997.

Möhler, O., DeMott, P. J., Vali, G., and Levin, Z.: Microbiology and atmospheric processes: the role of biological particles in cloud physics, Biogeosciences, 4, 1059-1071, doi:10.5194/bg-4-10592007, 2007.

Murphy, D. M., Cziczo, D. J., Froyd, K. D., Hudson, P. K., Matthew, B. M., Middlebrook, A. M., Peltier, R. E., Sullivan, A., Thomson, D. S., and Weber, R. J.: Single-particle mass spectrometry of tropospheric aerosol particles, J. Geophys. Res., 111, D23S32, doi:10.1029/2006JD007340, 2006.

Murphy, D. M., Hudson, P. K., Cziczo, D. J., Gallavardin, S., Froyd, K. D., Johnston, M. V., Middlebrook, A. M., Reinard, M. S., Thomson, D. S., Thornberry, T., and Wexler, A. S.: Distribution of lead in single atmospheric particles, Atmos. Chem. Phys., 7, 3195-3210, doi:10.5194/acp-7-3195-2007, 2007.

Parungo, F. P. and Allee, P. A.: Rocket effluent: Its nucleation activity and related properties, J. Appl. Meteor., 17, 1856-1863, 1978.

Phillips, V. T. J., De Mott, P. J., and Andronache, C.: An empirical parametrization of heterogeneous ice nucleation for multiple chemical species of aerosol, J. Atmos. Sci., 65, 2757-2783, 2008.

Posfai, M., Anderson, J. R., and Buseck, P. R.: Soot and sulphate aerosol particles in the remote marine atmosphere, J. Geophys. Res., 104, 21685-21693, 1999.

Prenni, A. J., DeMott, P. J., Twohy, C., Poellot, M. R., Kreidenweis, S. M., Rogers, D. C., Brooks, S. D., Richardson, M. S., and Heymsfield, A. J.: Examinations of ice formation processes in Florida cumuli using ice nuclei measurements of anvil ice crystal particle residues, J. Geophys. Res., 112, D10221, doi:10.1029/2006JD007549, 2007.

Reischel, M. T. and Vali, G.: Freezing nucleation in aqueous electrolytes, Tellus, 27, 414-427, 1975.

Richardson, M. S., DeMott, P. J., Kreidenweis, S. M., Cziczo, D. J., Dunlea, E. J., Jimenez, J. L., Thomson, D. S., Ashbaugh, L. L., Borys, R. D., Westphal, D. L., Casuccio, G. S., and Lersch, T. L.: Measurements of heterogeneous ice nuclei in the western United
States in springtime and their relation to aerosol characteristics, J. Geophys. Res., 112, D02209, doi:10.1029/2006JD007500, 2007.

Roberts, P. and Hallett, J.: A laboratory study of the ice nucleating properties of some mineral particulates, Q. J. Roy. Meteorol. Soc., 94, 25-34, 1968.

Rogers, D. C., De Mott, P. J., and Kreidenweis, S. M., Airborne measurements of tropospheric ice-nucleating aerosol particles in the Arctic spring, J. Geophys. Res., 106, 15053-15063, 2001.

Rosinski, J.: Cloud condensation nuclei as a real source of ice forming nuclei in continental and marine air masses. Atmos. Res., 38, 351-359, 1995.

Schäfer, V. J.: Ice nuclei from automobile exhaust and iodine vapour, Science, 154, 1555-1557, 1966.

Schaller, R. C. and Fukuta, N.: Ice nucleation by aerosol particles: Experimental studies using a wedge-shaped ice thermal diffusion chamber, J. Atmos. Sci., 36, 1788-1802, 1979.

Schnell, R. C. and Vali, G.: Atmospheric ice nuclei from decomposing vegetation, Nature, 236, 163-165, 1972.

Shotyk, W. and Le Roux, G.: Biogeochemistry and Cycling of Lead, in "Biogeochemical Cycles of the Elements", Vol. 43 of Metal Ions in Biological Systems, edited by: Sigel, A., Sigel, H., Sigel, O. R. K., and Dekker, M., New York, 240-275, 2005.

Szymer, W. and Zawadzki, I.:, Biogenic and Anthropogenic Sources of Ice-Forming Nulcei: A Review, Bull. Am. Meteorol. Soc., 78(2), 209-228, 1997.

Targino, A. C., Krejci, R., Noone, K. J., and Glantz, P.: Single particle analysis of ice crystal residuals observed in orographic wave clouds over Scandinavia during INTACC experiment, Atmos. Chem. Phys., 6, 1977-1990, doi:10.5194/acp-6-1977-2006, 2006.

Twohy, C. H. and Poellot, M. R.: Chemical characteristics of ice residual nuclei in anvil cirrus clouds: evidence for homogeneous and heterogeneous ice formation, Atmos. Chem. Phys., 5, 2289 2297, doi:10.5194/acp-5-2289-2005, 2005.

Utsunomiya, S., Jensen, K. A. , Keeler, G. J., and Ewing, R. C.: Direct identification of trace metals in fine and ultrafine particles in the Detroit urban atmosphere, Environ. Sci. Technol., 38, 2289-2297, 2004.

Verheggen, B., Cozic, J., Weingartner, E., Bower, K., Mertes, S., Connolly, P., Gallagher, M., Flynn, M., Choularton, T., and Baltensperger, U.: Aerosol partitioning between the interstitial and the condensed phase in mixed-phase clouds, J. Geophys. Res., 112, D23202, doi:10.1029/2007JD008714, 2007.

Vester, B. P., Ebert, M., Barnert, E. B., Schneider, J., Kandler, K., Schütz, L., and Weinbruch, S.: Composition and mixing state of the urban background aerosol in the Rhein-Main area (Germany), Atmos. Environ., 41(29), 6102-6115, 2007.

Vidaurre, G. and Hallet, J.: Particle Impact and Breakup in Aircraft Measurement, J. Atmos. Ocean. Tech., 26, 97983, doi:10.1175/2008JTECHA1147.1, 2009.

Wallace J. M. and Hobbs, P. V.: Atmospheric science: an introductory survey, 2nd ed., International Geophysics Series, Academic Press, Elsevier Inc., 483 pp., 2006.

Weingartner, E., Burtscher, H., and Baltensperger, U.: Hygroscopic properties of carbon and diesel soot particles, Atmos. Environ., 31, 2311-2327, 1997.

Wentzel, M., Gorzawski, H., Naumann, K.-H., Saathoff, H., and Weinbruch, S.: Transmission electron microscopical and aerosol 
dynamical characterization of soot aerosols, J. Aerosol Sci., 34, 1347-1370, 2003.

Zimmermann F., Ebert, M., Worringen, A., Schütz, L., and Weinbruch, S.: Environmental scanning electron microscopy (ESEM) as a new technique to determine the ice nucleation capability of individual aerosol particles, Atmos. Environ., 41, 8219-8227, 2007.
Zimmermann, F., Ebert, M., Hoffmann, H., Kandler, K., Schütz, L., Worringen, A., and Weinbruch, S.: Ice nucleation properties of the most abundant mineral dust phases, J. Geophys. Res., 113, D23204, doi:10.1029/2008JD010655, 2008.

Zuberi, B., Bertram, A. K., Cassa, C. A., Molina, L. T., and Molina, M. J.: Heterogeneous nucleation of ice in (NH4)2SO4-H2O particles with mineral dust immersions, Geophys. Res. Lett., 29, 1504, doi:10.1029/2001GL014289, 2002. 